\title{
Marine notches in the Maltese islands (central Mediterranean Sea)
}

\author{
Stefano Furlani a, *, Fabrizio Antonioli b, Timmy Gambin ${ }^{\mathrm{c}}$, Ritienne Gauci ${ }^{\mathrm{d}}$, \\ Andrea Ninfo ${ }^{\mathrm{e}}$, Enrico Zavagno ${ }^{\mathrm{a}}$, Anton Micallef ${ }^{\mathrm{f}}$, Franco Cucchi ${ }^{\mathrm{a}}$ \\ a Department of Mathematics and Geosciences, University of Trieste, Italy \\ ${ }^{\mathrm{b}}$ ENEA, Casaccia, Modeling of Climate Change Laboratory, Rome, Italy \\ ${ }^{\mathrm{c}}$ Department of Classics and Archaeology, University of Malta, Malta \\ d Department of Geography, University of Malta, Malta \\ e Department of Geosciences, University of Padua, Italy \\ ${ }^{\mathrm{f}}$ Institute of Earth Systems, University of Malta, Malta
}

\section{A R T I C L E I N F O}

\section{Article history:}

Available online 25 July 2016

\section{Keywords:}

Coastal geomorphology

Tidal notches

Roof notches

Geoswim

Malta

\begin{abstract}
A B S T R A C T
We present the first detailed survey of tidal notches in the central Mediterranean area, in particular along the coastline of Gozo and Comino (Malta). The Maltese Islands represent one of the few sites in the Sicily Channel which exhibits coastal carbonate rocks. Marine notches on the islands of Gozo and Comino were surveyed by means of a seven day continuous snorkeling survey around the entire perimeter of the two islands. We surveyed the occurrence, lack and typology of marine notches and we correlated them with late Holocene sea level changes. Sea temperature (T) and electrical conductivity (EC) were collected along the route in order to locate the submarine springs and to relate them to the surveyed notches.

A well-carved continuous roof notch was discovered along most of the plunging cliffs. It is well-carved out, in particular along the northern and western coast of Gozo. It develops from about $0.2 \mathrm{~m}$ above the mean sea level down and it can be up to $1.5-2 \mathrm{~m}$ deep. On the contrary, tidal notches are localised only in 8 sites. In 2 sites, Vermetid trottoirs develop at low tide level. In addition, at about $-7 \mathrm{~m}$ to $-10 \mathrm{~m} \mathrm{~m} . \mathrm{s} . \mathrm{l}$., a $2-5 \mathrm{~m}$ wide marine terrace develops along extensive tracts of plunging cliffs, always in correspondence with the roof notches. This submerged terrace seem to be the result of the late Holocene slowdown of the sea level rise, which started to smooth the terrace and to carve out the submerged part of the roof notch, thanks to the exposed location of the islands and the favourable lithology.

Through the collection of hydrological data, the presence of 21 submarine springs were detected. They occur mainly in the south-western coast of Gozo and on eastern coast of Comino. Anyway, marine notches seem not to be related to the freshwater outflow, such as those in the Adriatic Sea, because the studied islands are very exposed. As a consequence, along the Maltese islands bioerosion seems to be the most effective process in notch development.
\end{abstract}

() 2016 Elsevier Ltd and INQUA. All rights reserved.

\section{Introduction}

The Mediterranean Sea is bordered by more than $60 \%$ of rocky coasts, but very short sectors were extensively surveyed in the field (Furlani et al., 2014a), mainly because of the challenging accessibility present on the typology of these coasts. Anyway, some carbonate coastal sectors are fundamental for the development of marine notches, such as the Maltese Islands (Fig. 1). They represent one of the few sectors of the Sicily Channel with carbonate coasts, so they represent one of the most favourable environments for the

\footnotetext{
* Corresponding author

E-mail address: sfurlani@units.it (S. Furlani).
}

development of marine notches in the central Mediterranean. The elevation of marine notches with respect to actual sea level is fundamental to evaluate the relative sea level changes.

Notches develop as a result of the higher erosion rates in the tidal zone rather than in the supratidal or subtidal zone (Furlani et al., 2009, 2010; Furlani \& Cucchi, 2013; Moses, 2012; Moses et al., 2014). These type of notches are called tidal notches, u-shaped, as suggested and described by Pirazzoli (1986). Antonioli et al. (2006) and Carobene and Pasini (1982) described the morphometric features of tidal notches in the central Mediterranean. Tidal notches are common features along Mediterranean sloping or vertical limestone cliffs and are widely used as sea level markers (e.g. Pirazzoli et al., 1996; Antonioli et al., 2006; Faivre et al., 2011; Evelpidou et al., 2014; Antonioli et al., 2015). Roof notches are 


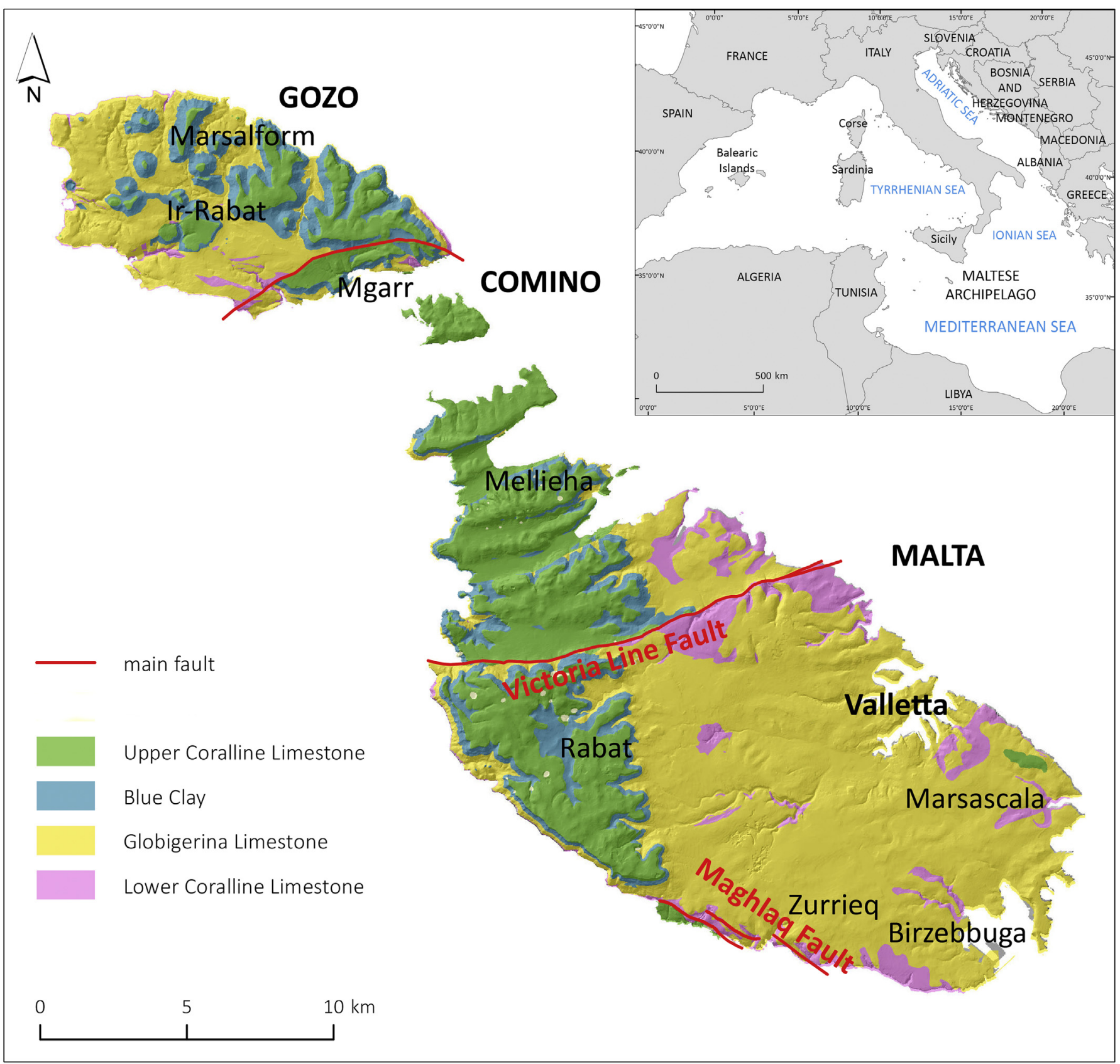

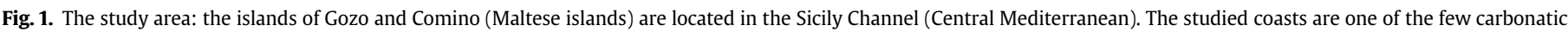

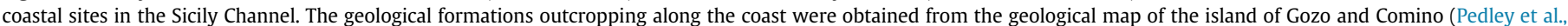
1978).

e-shaped (sensu Pirazzoli, 1986) and are characterized by an asymmetrical shape and well-developed roof top. They were identified and surveyed by many authors such as Benac et al. (2004, 2008) in the Gulf of Kvarner (Croatia), and Antonioli et al. (2007) and Furlani et al. (2011) in the Eastern Adriatic Sea. The morphometric features of roof notches were described by Benac et al. (2004, 2008) and Antonioli et al. (2015). Despite their importance in sea level change studies, their genesis and development are still not fully understood. Evelpidou et al. (2012) really suggested the global disappearance of present-day tidal notches. Most studies suggest that tidal notches are the result of bioerosional processes in sheltered or exposed sites (e.g. Focke, 1978; Pirazzoli, 1986), but some literature also supported the contribution of groundwater effects as the primary agent (Higgins, 1980) in view of the proximity of notches to submarine springs and suggested a one to one ratio between notches and submarine springs in Greece. Furlani et al. (2014a, 2014b) obtained the same results in the northeastern Adriatic Sea. Wave abrasion plays little or no contribution in notch cutting, both because of the usual lack of tools for abrasion close to the notch and because tidal and roof notches in the Mediterranean are absent in rocks other than limestones (Higgins, 1980), unlike other sites outside the Mediterranean (Trenhaile, 2015). Kaye (1957) suggested that agitation of surface water might act like an enhanced solution process.

Micallef et al. (2013) reconstructed the submerged morphology in the near off-shore of the Maltese Islands, whilst Furlani et al. (2013) reconstructed the evolution of the Holocene sea level rise and the paleo-connections with Sicily. 
This paper presents geomorphological and hydrogeological data collected during the first continuous snorkel survey of the islands of Gozo and Comino, following the method used for the survey of the northeastern Adriatic coasts by Furlani et al. (2014b). Considering the importance of marine notches in the context of the Mediterranean area, we focused mainly on the intertidal zone, by the identification of present-day notches and their relations with current and past sea levels in the central part of the basin. Moreover, hydrological data, namely temperature and electrical conductivity, were collected in order to identify submarine springs and discuss their relations with marine notches.

\section{Physical setting}

The islands of Gozo $\left(65.79 \mathrm{~km}^{2}\right)$ and Comino $\left(2.76 \mathrm{~km}^{2}\right)$ are part of the Maltese archipelago located in the middle of the Mediterranean Sea (Said \& Schembri, 2010), in the Sicily Channel (Fig. 1), between Sicily ( $80 \mathrm{~km}$ northward) and the African coasts (about $300 \mathrm{~km}$ Westward).

From a geological point of view, a sedimentary sequence mainly composed by carbonate rocks spanning in time from Upper Oligocene to Upper Miocene crops out in Malta and Gozo. Along the coast, four formations outcrop: Lower Coralline Limestone Formation (Chattian), Globigerina Limestone Formation (AquitanianEarly Langhian), Blue Clay Formation (Langhian-Tortonian) and Upper Coralline Limestone Formation (Late Tortonian-Early Messinian) (Pedley et al., 1978). According to Schembri (2003), 61.8 per cent of the Island of Gozo is characterised by Lower Coralline
Limestone and most of this formation is exposed on the western side of the island.

The island of Gozo has an easterly dip forming high Lower Coralline Limestone cliffs on the west coast, whilst north and south coasts of Comino slope gently to the sea and with high cliffs evident only on the northeast coast. The topography of the Islands is strongly controlled by the horst and graben system developed during Miocene and Plio-Quaternary extensional stages (Furlani et al., 2013).

With regards to the recent tectonic movements of the Maltese Islands, Furlani and Cucchi (2013) investigated some archaeological remains on mainland Malta. The research provided an estimation of the relative sea level changes and vertical displacements of Malta since $3.3 \mathrm{ky}$ BP. The submerged structures indicate that their elevations are in agreement with the predicted sea level curve (Lambeck et al., 2011), implying a relative stability for late Holocene.

The coastal geomorphology of the Maltese Islands was treated by Anzidei et al. (2014), Paskoff and Sanlaville (1978), Ellenberg (1983) and Schembri (2003) and reviewed recently by Said and Schembri (2010). Said and Schembri (2010) identified five morphotypes: plunging cliffs, scree-sloping coasts, smooth sloping platforms, stepped platforms and pocket beaches. Gozo resulted mainly dominated by plunging cliffs in the southern and northwestern sector, while scree-sloping coasts, locally so-called Rdum (Said \& Schembri, 2010), are located in the northeast (Table 2) and were studied by Devoto et al. (2012) and Mantovani et al. (2013) and mapped by Biolchi et al. (2016).

Table 1

Route followed during the field surveys and hydrological data. Meteorological data were taken from: Malta Weather Station, Qrendi, Lat: $35.8833^{\circ} \mathrm{N}$, Long: $14.5000^{\circ} \mathrm{E}$.

\begin{tabular}{|c|c|c|c|c|c|c|c|c|c|c|c|}
\hline Step & Date & Place of departure & Place of arrival & $\begin{array}{l}\text { Length } \\
(\mathrm{km})\end{array}$ & Winds $(\mathrm{km} / \mathrm{h})$ & $\begin{array}{l}\mathrm{EC} \min (\mathrm{mS} / \\
\mathrm{cm})\end{array}$ & $\begin{array}{l}\text { EC mean }(\mathrm{mS} / \\
\mathrm{cm})\end{array}$ & $\begin{array}{l}\mathrm{EC} \max (\mathrm{mS} / \\
\mathrm{cm})\end{array}$ & $\begin{array}{l}\mathrm{T} \text { min } \\
\left({ }^{\circ} \mathrm{C}\right)\end{array}$ & $\begin{array}{l}\text { T mean } \\
\left({ }^{\circ} \mathrm{C}\right)\end{array}$ & $\begin{array}{l}\mathrm{T} \max \\
\left({ }^{\circ} \mathrm{C}\right)\end{array}$ \\
\hline 1 & $\begin{array}{l}26 \text { July } \\
2013\end{array}$ & Marsalforn & Ramla Bay & 3.1 & $\begin{array}{l}249^{\circ} \text { WSW } \\
(1.8)\end{array}$ & 55.18 & 56.06 & 56.97 & 28.68 & 29.03 & 30.62 \\
\hline 2 & $\begin{array}{l}27 \text { July } \\
2013\end{array}$ & Mgarr & Tà Sannat & 5.74 & $\begin{array}{l}284^{\circ} \mathrm{WNW} \\
(1.5)\end{array}$ & 56.36 & 57.54 & 58.46 & 26.37 & 27.19 & 29.4 \\
\hline 3 & $\begin{array}{l}28 \text { July } \\
2013\end{array}$ & Xlendi & Tà Sannat & 5.39 & $\begin{array}{l}340^{\circ} \mathrm{NNW} \\
(4.1)\end{array}$ & 49.28 & 57.03 & 57.27 & 25.67 & 26.59 & 27.77 \\
\hline 4 & $\begin{array}{l}29 \text { july } \\
2013\end{array}$ & Dahlet Qorrot & Mġarr & 6.96 & $\begin{array}{l}333^{\circ} \mathrm{NNW} \\
(8.1)\end{array}$ & 48.30 & 57.04 & 57.54 & 26.12 & 27.47 & 28.66 \\
\hline 5 & $\begin{array}{l}30 \text { July } \\
2013\end{array}$ & Ramla Bay & Dahlet Qorrot & 4.31 & $\begin{array}{l}325^{\circ} \mathrm{NW} \\
(12.4)\end{array}$ & 1 & 1 & 1 & 1 & 1 & 1 \\
\hline Stop & $\begin{array}{l}31 \text { July } \\
2013\end{array}$ & 1 & 1 & 1 & $356^{\circ} \mathrm{N}(5.2)$ & 1 & 1 & I & 1 & 1 & 1 \\
\hline 6 & $\begin{array}{l}\text { 01 Aug } \\
2013\end{array}$ & $\begin{array}{l}\text { Blue Lagoon } \\
\text { (Comino) }\end{array}$ & $\begin{array}{l}\text { Blue Lagoon } \\
\text { (Comino) }\end{array}$ & 11.0 & $207^{\circ} \mathrm{SSW}(3.6)$ & 55.13 & 57.07 & 57.50 & 25.89 & 27.04 & 28.42 \\
\hline 7 & $\begin{array}{l}02 \text { Aug } \\
2013\end{array}$ & Dimitri Point & Xlendi & 11.2 & $27^{\circ} \mathrm{NNE}(7.5)$ & 53.51 & 56.90 & 57.51 & 25.68 & 26.41 & 29.4 \\
\hline 8 & $\begin{array}{l}03 \text { Aug } \\
2013\end{array}$ & Marsalforn & Dimitri Point & 9.26 & $\begin{array}{l}294^{\circ} \text { WNW } \\
(2.6)\end{array}$ & 55.20 & 56.98 & 57.72 & 25.06 & 26.69 & 28.64 \\
\hline TOT & & & & 56.96 & & & & & & & \\
\hline
\end{tabular}

Table 2

Submarine springs along the Gozo and Comino coast.

\begin{tabular}{|c|c|c|c|c|c|c|}
\hline Number & Latitude & Longitude & $\mathrm{T}\left({ }^{\circ} \mathrm{C}\right)$ & $\mathrm{EC} \min (\mathrm{mS})$ & Coastal morphotype & Note \\
\hline 1 & 36.062417 & 14.190849 & 26.17 & 0.368 & Plunging cliff & \\
\hline 2 & 36.061258 & 14.191677 & 26.36 & 56.228 & Plunging cliff & \\
\hline 3 & 36.055206 & 14.190612 & 26.10 & 53.516 & Plunging cliff & Dweira \\
\hline 4 & 36.052146 & 14.188208 & 26.33 & 54.668 & Coastal slope & Dweira \\
\hline 5 & 36.047934 & 14.188970 & 26.41 & 53.668 & Plunging cliff & Dweira \\
\hline 6 & 36.047152 & 14.192724 & 26.43 & 56.072 & Sea cave & Dweira \\
\hline 7 & 36.046679 & 14.193015 & 26.57 & 56.564 & Sea cave & Dweira \\
\hline 8 & 36.045760 & 14.193160 & 26.38 & 56.316 & Sea cave & Dweira \\
\hline 9 & 36.021150 & 14.224593 & 26.02 & 56.052 & Plunging cliff & \\
\hline 10 & 36.018985 & 14.244671 & 27.59 & 57.100 & Plunging cliff & \\
\hline 11 & 36.017757 & 14.253283 & 26.67 & 56.364 & Plunging cliff & \\
\hline
\end{tabular}


Table 2 (continued)

\begin{tabular}{|c|c|c|c|c|c|c|}
\hline Number & Latitude & Longitude & $\mathrm{T}\left({ }^{\circ} \mathrm{C}\right)$ & $\mathrm{EC} \min (\mathrm{mS})$ & Coastal morphotype & Note \\
\hline 12 & 36.017015 & 14.271738 & 26.63 & 56.684 & Plunging cliff & Mgarr Ix-Xini \\
\hline 13 & 36.019421 & 14.288309 & 26.02 & 56.936 & Coastal slope & \\
\hline 14 & 36.026406 & 14.306448 & 26.93 & 56.856 & Coastal slope & \\
\hline 15 & 36.026683 & 14.321259 & 26.53 & 53.336 & Sea cave & \\
\hline 16 & 36.028321 & 14.325256 & 26.97 & 27.19 & Sea cave & \\
\hline 17 & 36.028254 & 14.325394 & 27.44 & 56.48 & Sea cave & Gebel Tal-Halfa \\
\hline 18 & 36.066536 & 14.272562 & 25.28 & 55.204 & Rdhum & Freshwater from river? \\
\hline 19 & 36.018909 & 14.340634 & 27.03 & 56.500 & Plunging cliff & E Comino \\
\hline 20 & 36.015508 & 14.344789 & 26.28 & 56.128 & Cliff & E Comino \\
\hline 21 & 36.012622 & 14.348770 & 26.38 & 55.128 & Cliff & E Comino \\
\hline
\end{tabular}

The island of Gozo is mainly composed of plunging cliffs (45.3 per cent), low sloping rock (30.6 per cent) and scree-sloping coasts (20.2 per cent). Only 2.9 per cent of the island is composed of sand deposits. The island of Comino is largely characterized by low sloping rock (60.6 per cent) and cliffs or steep rock face (29.8 per cent). Boulder screes are relatively less dominant compared to Gozo ( 7.8 per cent) and sandy shores represent only 1.6 per cent of the Comino coastline (Schembri, 2003). Semicircular coves, drowned sinkholes and other karst features are spread all over the island (Soldati et al., 2013). Most of the valleys are rias, previously excavated by fluvial processes, but today practically inactive (Paskoff \& Sanlaville, 1978).

The see bottom is particularly deep along the western part of Gozo, in correspondence of high plunging cliffs (up to $-70 \mathrm{~m}$ in the NW sector of Gozo) while the NE and SE sector are generally shallower (British Admiralty and U.S. charts, 1996).

The climate of the Maltese islands is typically Mediterranean, characterized by hot, dry long summer and mild and short winters (Grove \& Rackham, 2001). Weather and climate are strongly influenced by the sea and by the relatively flat morphology of the islands which does not favour rainfall formation. On average, the island receives $530 \mathrm{~mm}$ of rainfall per year (Schembri, 2003). Mean temperatures range from $12{ }^{\circ} \mathrm{C}$ to $27^{\circ} \mathrm{C}$. Due to the position of the Maltese Islands in the middle of Central Mediterranean, they are affected by long fetches mainly in the second and fourth quadrant (Galdies, 2011). Dominant winds come from NW (Galdies, 2011). The wave climate around the Maltese Islands is dominated by sea waves rather than swell waves: sea waves, generated by winds in the local area, are characterised by being steep and have relatively short wave periods when compared to swell waves which travel into the local area from elsewhere (Malta
Maritime Authority, 2003). Tidal oscillations, predominantly semidiurnal, reach a maximum range of only $20.6 \mathrm{~cm}$ on average for spring tides and is reduced to $4.6 \mathrm{~cm}$ during neap tides (Drago, 2009).

From a hydrogeological point of view, the Lower Coralline Limestone and the Upper Coralline Limestone are fissured and fractured formations with a porous matrix and well-developed karst phenomena. The Globigerina Limestone is a fissured and fractured formation with a porous matrix and with porous layer creating horizontal aquitard bodies (Pollacco, 2000). Chetcuti et al. (1992) estimated that between $16 \%$ and $25 \%$ of the annual rainfall infiltrates to recharge the aquifers. The largest aquifer is called the Main Sea level Aquifer and consists of a lens of freshwater floating on denser saline water in limestone rocks at sea level. At the Upper Coralline Limestone/Blue Clay interface freshwater springs can occur (Schembri, 1993).

Both Vermetus triquetus and Dendropoma petraeum were recognized along the Maltese Islands (Cachia et al., 1993). Vermetus occupies shallow-filled holes and depressions within and behind Dendropoma aggregations, in protected conditions (Azzopardi \& Schembri, 1997). In any case, Maltese Vermetid crusts are less developed than vermetid platforms in Sicily or from the eastern Mediterranean (Azzopardi \& Schembri, 1997) and they are best developed where marine erosion of soft rock results in subhorizontal platform at sea level. Vermetus triquetrus occupies more sheltered situations while $D$. petraeum occur where there is considerable wave action (Azzopardi \& Schembri, 1997).

\section{Method}

The continuous survey of the Gozo and Comino coastlines was carried out following Furlani (2012) and Furlani et al. (2014b) using
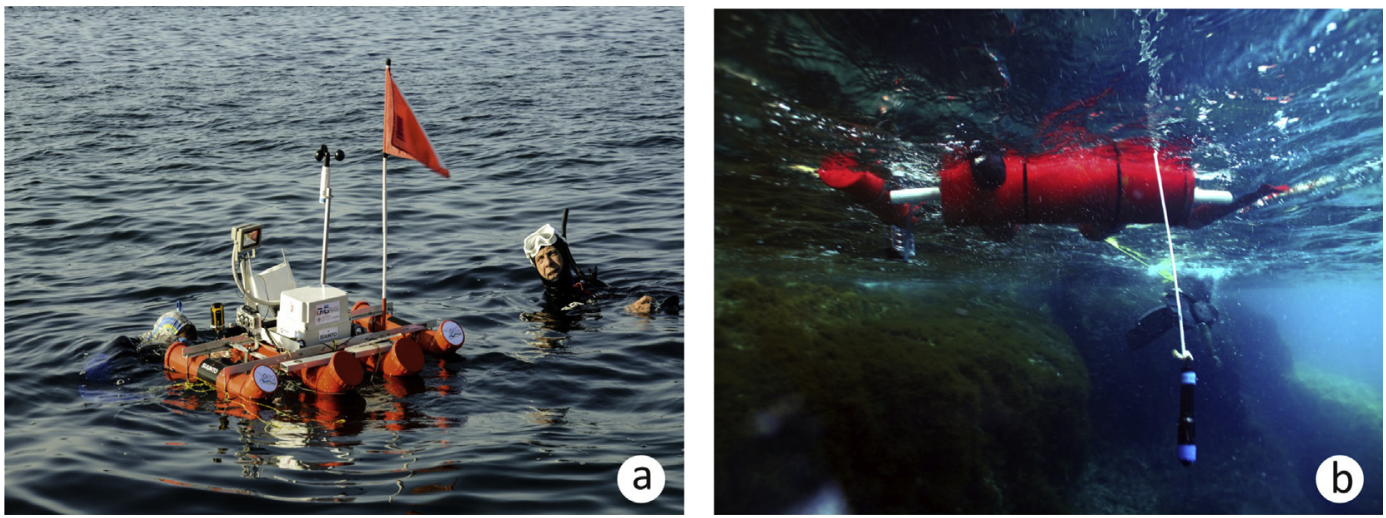

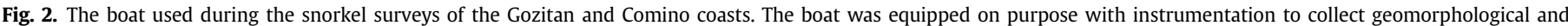

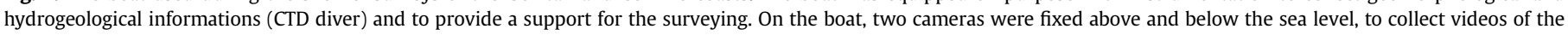
tidal zone and 3 lamps (2 waterproof lamps). 
a snorkeling swim techniques. The Geoswim project aims specifically at surveying large sections of rocky coasts by snorkeling and collecting data mainly on intertidal coastal landforms and hydrological setting (Furlani, 2012; Furlani et al., 2014b). A specially designed raft was built to house all the surveying equipment. The raft was pushed or dragged during the snorkelling activities. Two cameras, located on the $1.0 \mathrm{~m}$ long raft (Fig. 2a, b), a CANON G12 set in an underwater housing and the latter a 3D GoPro camera, allowed to collect an ongoing video of large part of the observed coast, both above and below the sea level. A CTD diver, produced by Eijkelkamp, was dragged in order to collect temperature and conductivity data along the route. Snorkel surveying was carried out swimming at around $1 \mathrm{~m}$ from the shoreline.

The occurrence of tidal or roof notches was surveyed and mapped (Figs. 3 and 5, Table 3). Notch morphometry was estimated following (Carobene, 1972, Carobene \& Pasini, 1982), Antonioli et al., (2015) and Furlani et al., (2011) using a metric rod. The more performing single-user profiling method, as suggested and used in Thailand by Kazmér and Taboroši (2012), was not adopted because the lower part of studied notches are partly submerged. We measured the following features: average notch width; average notch depth; its present bottom reef depth; depth of the cliff toe (Table 3).

Table 3

Morphometric features of tidal notches along the Gozo and Comino coast.

\begin{tabular}{|c|c|c|c|c|c|c|c|c|c|}
\hline Site & $\begin{array}{l}\text { WGS84 coordinates (lat; } \\
\text { long) }\end{array}$ & Lithology & $\begin{array}{l}\text { Average notch width } \\
\text { (m) }\end{array}$ & $\begin{array}{l}\text { Reef depth } \\
\text { (m) }\end{array}$ & $\begin{array}{l}\text { Notch depth } \\
\text { (m) }\end{array}$ & $\begin{array}{l}\text { Sea bottom depth } \\
(\mathrm{m})\end{array}$ & $\begin{array}{l}\text { Direction/ } \\
\text { Exposure }\end{array}$ & $\begin{array}{l}\text { Submarine spring } \\
(\mathrm{Y} / \mathrm{N})\end{array}$ & Notes \\
\hline 1 Xlendi & $36.028024 ; 14.212299$ & GLO & 0.65 & 1 & 0.40 & -20 & SW exposed & $\mathrm{N}$ & 1 \\
\hline 2 Dwejra & $36.046153 ; 14.189200$ & LCL & 0.95 & 0.80 & 0.80 & -8 & W exposed & Y & $\begin{array}{l}\text { Vermetid } \\
\text { reef }\end{array}$ \\
\hline 3 Dwejra & $36.052331 ; 14.188293$ & LCL & 0.90 & 2.00 & 0.85 & -8 & W exposed & Y & $\begin{array}{l}\text { Vermetid } \\
\text { reef }\end{array}$ \\
\hline $\begin{array}{c}4 \text { Ghar il- } \\
\text { Qamh }\end{array}$ & $36.081179 ; 14.230027$ & LCL & 0.70 & I & 0.85 & -25 & NW exposed & $\mathrm{N}$ & 1 \\
\hline $\begin{array}{l}6 \text { Tac-Cawl } \\
\text { Rocks }\end{array}$ & $36.026371 ; 14.317247$ & GLO & 0.75 & I & 0.90 & -15 & S sheltered & $\mathrm{N}$ & 1 \\
\hline $\begin{array}{l}7 \text { South } \\
\text { Comino }\end{array}$ & $36.004824 ; 14.335231$ & UCL & 0.55 & 0.40 & 0.80 & -10 & S sheltered & $\mathrm{N}$ & Continuous \\
\hline $\begin{array}{l}8 \text { South } \\
\text { Comino }\end{array}$ & $36.008825 ; 14.351190$ & UCL & 0.60 & 0.40 & 0.75 & -15 & E exposed & $\mathrm{N}$ & $\begin{array}{l}\text { Vermetid } \\
\text { reef }\end{array}$ \\
\hline
\end{tabular}

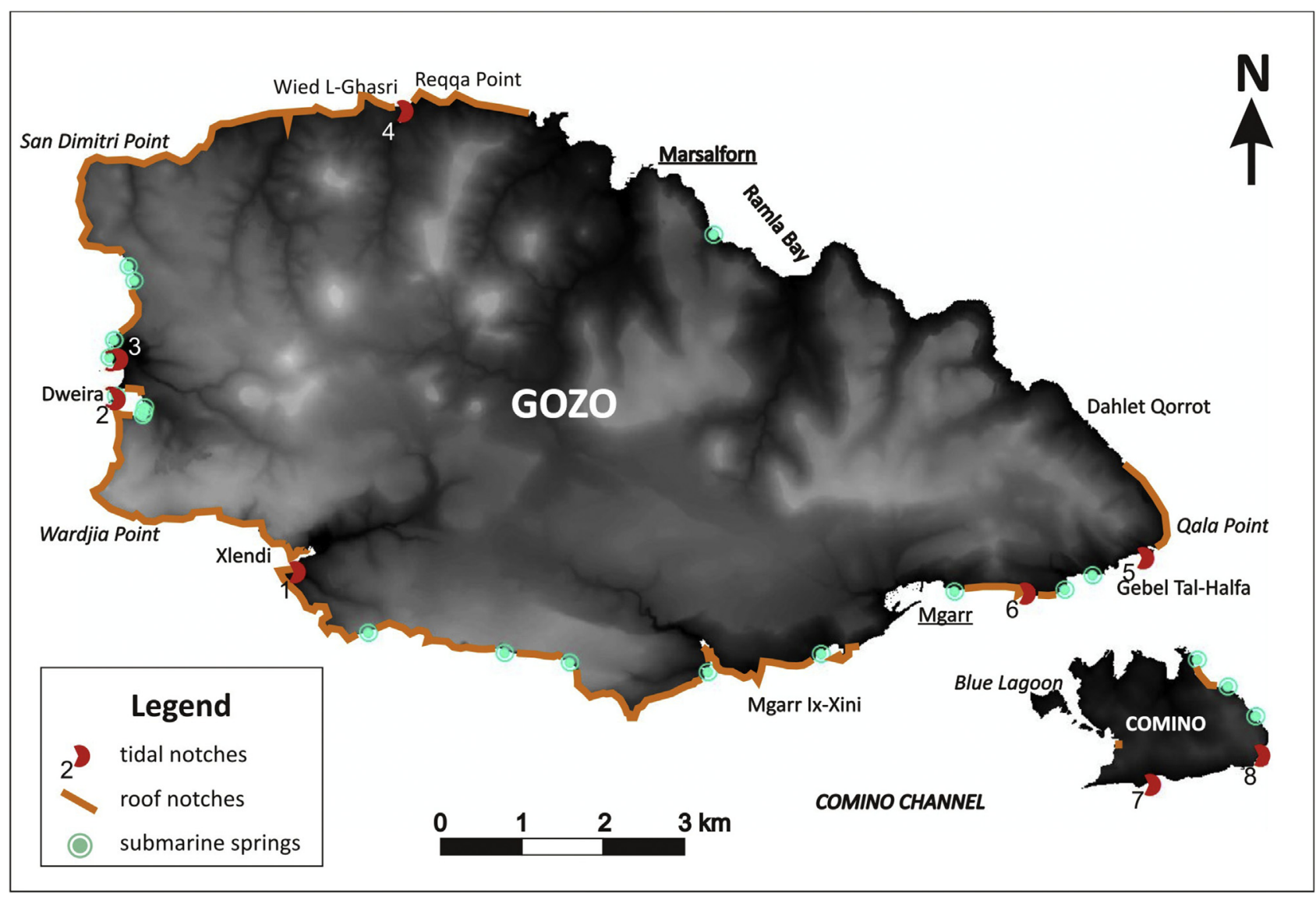

Fig. 3. Map of marine notches and submarine springs surveyed around the coast of Gozo and Comino. 


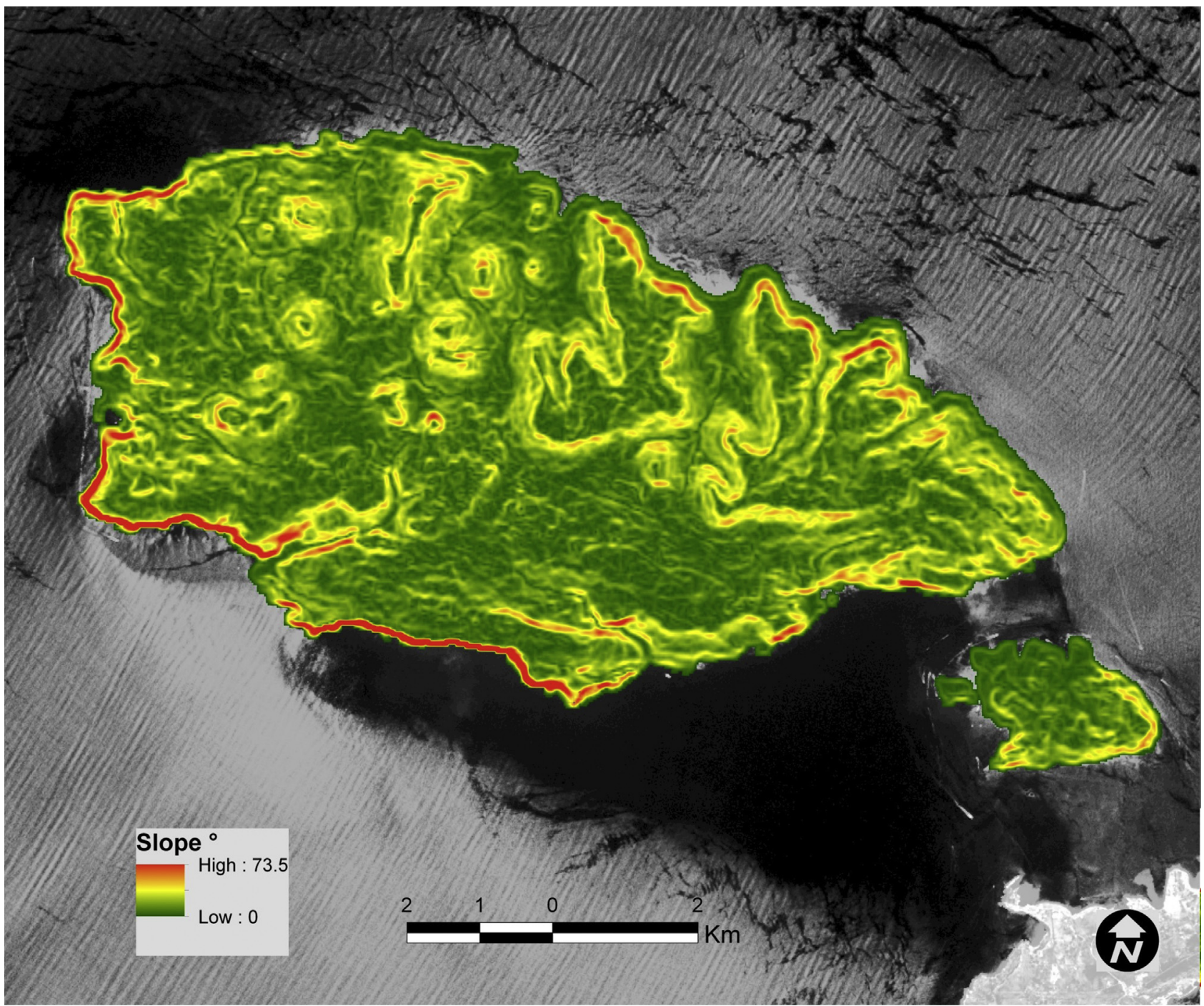

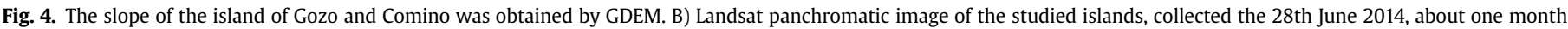
before the swimming survey. The sea conditions are dominated by northwesterly winds, as most of the surveying days of the project.

Morphometric features of tidal notches were collected at 8 sites (Table 3 ) along the route and the given values represent a mean value of repeated measures with only a small error bar (less than $\pm 10 \mathrm{~cm}$ ) due to the difficult logistics of the surveys (Fig. 5c). The uncertainty in the elevation measurements with respect to the sea level surface, or the tide, was negligible during the surveying period.

A data-logger (CTD Diver) was installed to measure (every $2 \mathrm{~s}$ ) electrical conductivity (EC) and temperature (T) along the surveyed coast. The accuracy, provided by the producer, was $\pm 0.1^{\circ} \mathrm{C}(\mathrm{T})$ and $\pm 1 \%$ (EC). Hydrological data was collected with the sole purpose of identifying and locating the submarine springs along the coasts of Gozo and Comino through abrupt changes of temperature and electrical conductivity. However, swimming at about $2-3 \mathrm{~km} / \mathrm{h}$, temperature data can be affected by a strong thermal inertia, preventing the fast equilibrium of the thermal CTD Diver sensor. The determination of the true value of conductivity can be also affected by a film of saltwater on the instrument, which can provide false values in correspondence of the submarine spring. CTD data and GPS data were synchronised and processed to correlate the conductivity and temperature, since data was collected following the favourable wind driven currents. The $98 \%$ of the coastline of Gozo and Comino was covered during the survey.

The slope analysis was carried out in order to highlight the coastal areas favourable to the development of the studied landforms; a topographic map derived DEM (cell size $10 \mathrm{~m}$, Fig. 3) and the GDEM-v2 (Global Digital Elevation Map, cell size $30 \mathrm{~m}$ ) was used for this application. Despite the resolution, GDEM results more realistic to classify the natural coastal slope (Fig. 4, Tables 2 and 3).

A Landsat 8 scene, acquired near the survey (28-06-2013) was analysed. In particular the coastal (OLI band 1: $0.4333-0.453 \mu \mathrm{m}$ ), TIR (Thermal Infrared) bands and Panchromatic were investigated to understand the conditions of the coastal waters during the surveying period. The typical setting, created by dominant wind and topography of the islands is clearly visible also in the Panchromatic (Fig. 4).

\section{Results}

Morphometric data on tidal notches are presented in Table 3. The map in Fig. 3 provides the location of tidal notches and the 

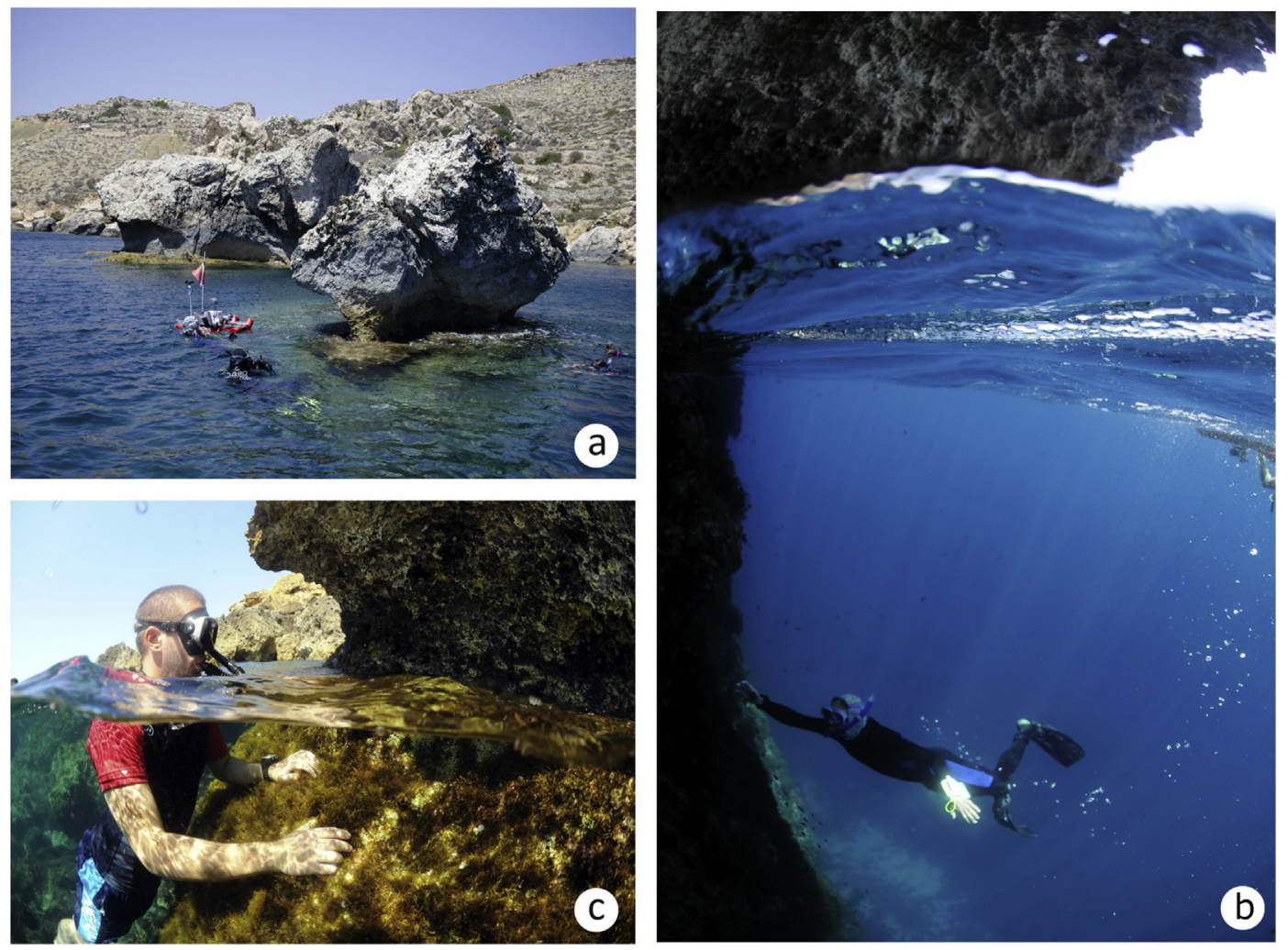

Fig. 5. Examples of notches surveyed around the island of Gozo and Comino. A) tidal notch with vermetid terrace at the mean tide, B) tidal notch, C) roof notch.

sectors of coast along which roof notches were observed and the location of submarine springs. In addition, we present hydrological data, namely temperature and conductivity, collected along the $91 \%$ of the surveyed coasts to find out submerged springs (Figs. 6 and 7).

\subsection{Tidal and roof notches}

Two types of notches have been recognised along the coastline of Gozo and Comino: tidal notches (Fig. 5B), sometimes with a large vermetid trottoirs at the low tide level (Fig. 5A) and roof notches (Fig. 5C).

Tidal notches, as the name suggests, develop in the intertidal zone and show a symmetric shape (Fig. 5B). They were surveyed in areas from very sheltered to moderately sheltered, and the sites are always protected by the dominant northwestern winds (Fig. 3). Tidal notches develop on Lower Coralline Limestone at Dwejra, in correspondence with the inner margin of a coastal doline (Soldati et al., 2013), or inside deep calanques, such as at Xlendi, in the south, and at Wier L-Ghasri, in the north. They can be found also in some small embayments at Qala Point, in the southeastern sector of Gozo. Tidal notches were also observed in the southern part of Comino, on Upper Coralline Limestone. Tidal notches in others sectors are restricted to very small sections of coast where the low depth, or the particular lithological/structural conditions, prevent the formation of roof notches, such as at Xlendi and Weird L-Ghasri, in the northern sector of Gozo. The width ranges between $0.65 \mathrm{~m}$ and $0.95 \mathrm{~m}$ (Table 3), while the notch depth ranges between $0.55 \mathrm{~m}$ and $0.95 \mathrm{~m}$. Sometimes, an algal trottoir occurred at the mean tide level. In particular, a large vermetid trottoir was observed in two sites: Dwejra (western Gozo) and Qala Point (eastern Gozo) (Fig. 3). The trottoir is constituted mainly by $V$. triquetrus. The reef depth ranges between $0.40 \mathrm{~m}$ and $0.90 \mathrm{~m}$.

The profile of roof notches show an asymmetric shape (Fig. 5C), with the retreat point roughly at the mean sea level or some tens centimetres above the mean sea level. The roof was measured at an average elevation of about $0.2 \pm 0.1 \mathrm{~m}$ m.s.l. above the maximum retreat point along all the studied coast. The roof depth varies from about $0.3 \mathrm{~m}$ up to $2.5 \mathrm{~m}$, depending on multiple local factors, such as lithology, exposure, etc. Roof notches occur with continuity along most of the plunging cliffs in southern and western Gozo, between Mgarr Ix-Xini and Reqqa Point, in the eastern side, at Gebel Tal-Halfa and short sectors at Comino.

The depth at the base of roof notches and tidal notches, ranging from $-7 \mathrm{~m}$ to some tens meters, while the depth at the base of the terrace notch is very low, few meters.

Moreover, at a depth ranging between $-7 \mathrm{~m}$ and $-10 \mathrm{~m}$, a 2-5 $\mathrm{m}$ large marine terrace occurs along most of the plunging cliffs, in correspondence of roof notches.

No other emerged or submerged notches, above or below the mean sea level, were recognised all over the study area.

\subsection{Hydrological data and freshwater springs}

Temperature and conductivity of the seawater are summarized in Tables 1 and 2 and shown in Fig. 6. Conductivity ranged between $48.3 \mathrm{mS} / \mathrm{cm}$ (29th July) and $58.46 \mathrm{mS} / \mathrm{cm}$ (27th July), while temperature between $25.06{ }^{\circ} \mathrm{C}$ and $30.62{ }^{\circ} \mathrm{C}$. Average conductivity ranged between $56.06 \mathrm{mS} / \mathrm{cm}$ and $57.54 \mathrm{mS} / \mathrm{cm}$, while the average temperature between $26.41{ }^{\circ} \mathrm{C}$ and $29.03{ }^{\circ} \mathrm{C}$.

Freshwater springs, when not directly observable in the field through the deterioration of water turbidity (Fig. 8B), were well detected as a result of abrupt changes in electric conductivity (up to $11 \mathrm{mS} / \mathrm{cm}$ ) at 17 sites in Gozo, mainly along the western and southern coast, and 3 in Comino, along the eastern sector of the island. 9 of the measured anomalies in conductivity were surveyed in correspondence with so many sea caves.

The peaks of minimum EC can be sometimes related to the peaks of minimum temperature (Fig. 5A). Significant reduction in 


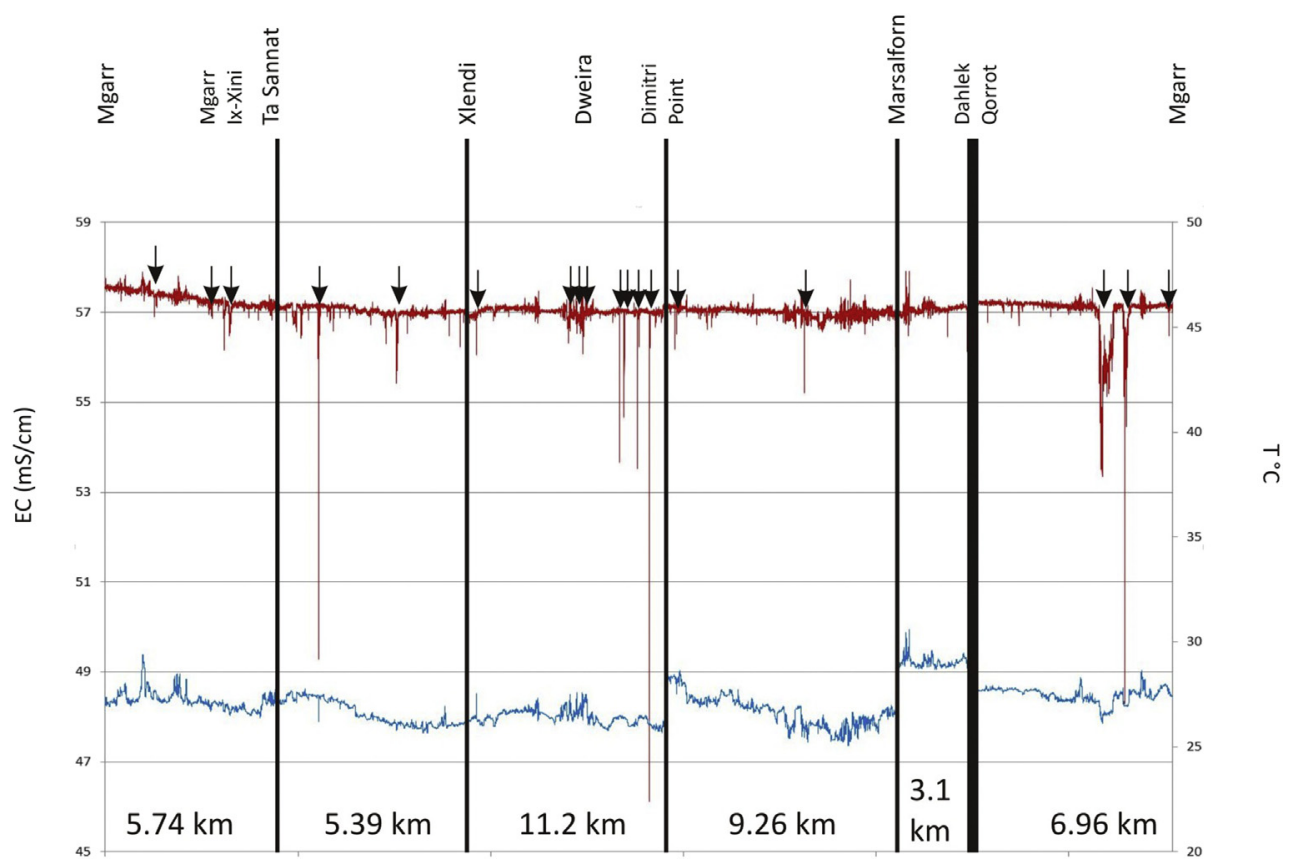

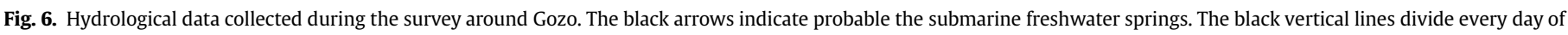
survey.
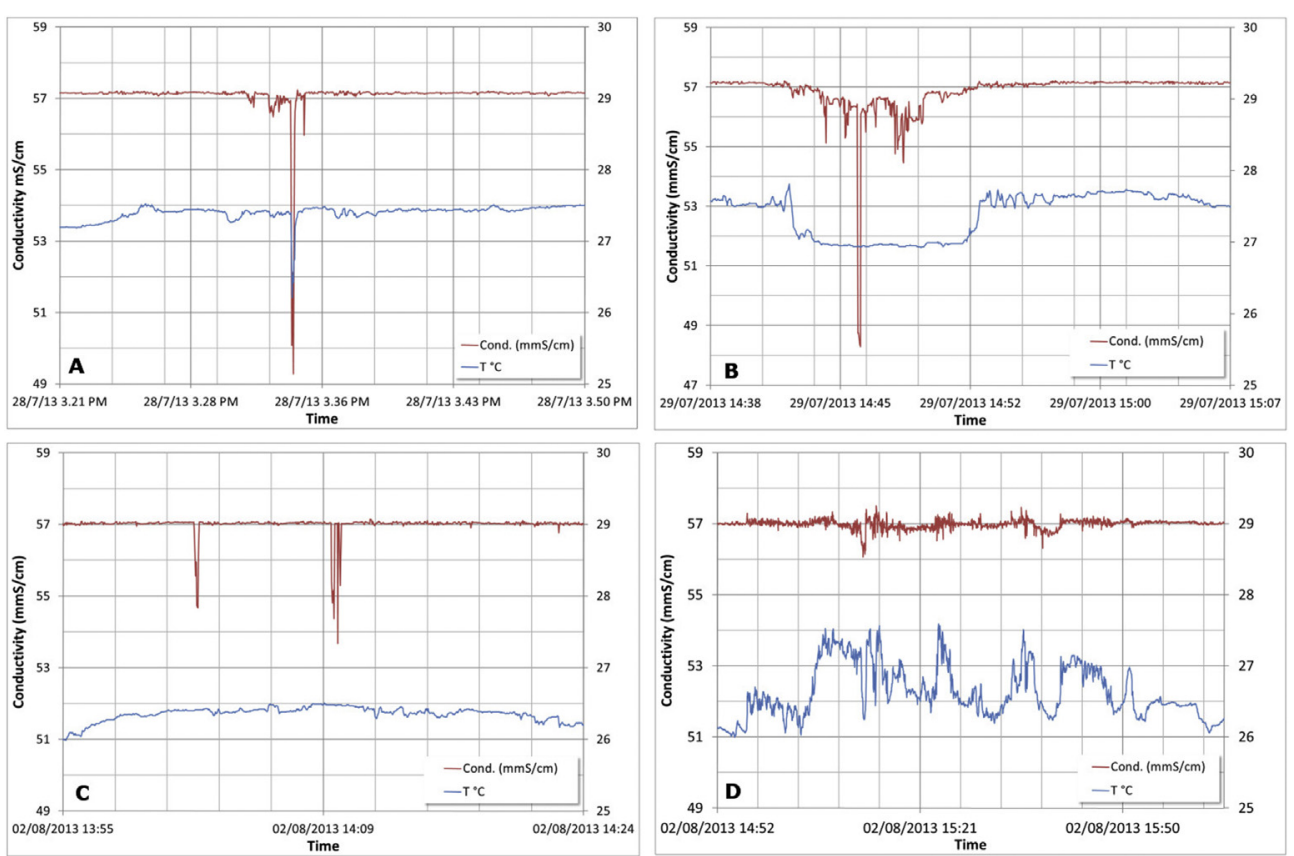

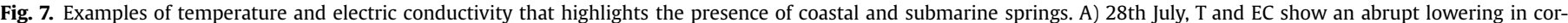

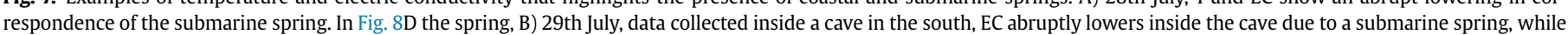

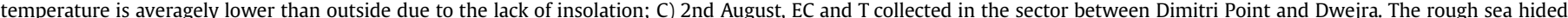

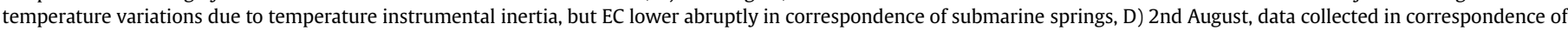
3 small caves in the bay of Dwejra.

sea temperature, which were measured in very sheltered caves (Table 2), are related also to minimum peaks in EC (Fig. 7B).

\section{Discussion}

The rocky coasts of Gozo and Comino are the result of a complex interaction between the lithology, marine and karst processes and late Holocene sea level rise. These interactions are discussed to explain the genesis and development of the roof notches and tidal notches surveyed along the Gozitan and Comino coast.

Said and Schembri (2010) suggested that coastal landforms along the Maltese islands are influenced by the structural setting. The topography is in fact strongly controlled by the horst and graben system, where bays correspond to downthrown blocks and 

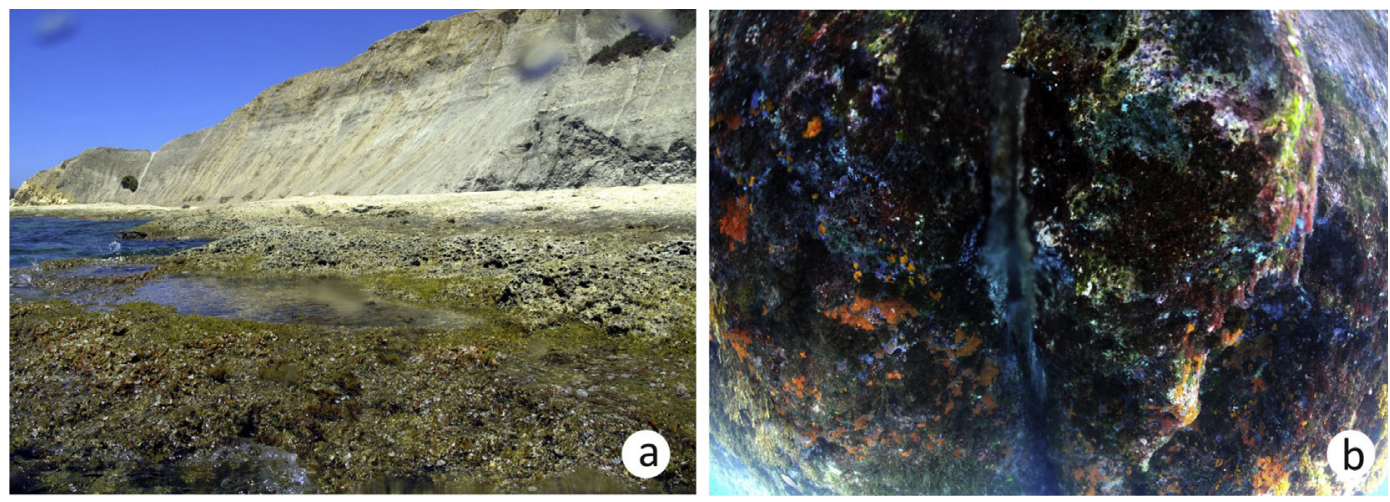

Fig. 8. A) vermetid reefs east from Mgarr; B) submarine spring (data in Fig. 7A).

headlands correspond to uplifted blocks (Devoto et al., 2012). Thus, the occurrence of coastal morphotypes and related coastal landforms are structurally and, consequently, also lithologically controlled (Table 2). Differences in erosion rates of the various rocky outcrops in the coastal sectors determine another important discriminating factor in the local coastal evolution. Micallef and Williams (2006) provided the average denudation rates of Lower Coralline Limestone Formation $(0.77 \mathrm{~mm} / \mathrm{yr})$, Upper Coralline Limestone $(1.38 \mathrm{~mm} / \mathrm{yr})$ and Globigerina Limestone (between $0.74 \mathrm{~mm} / \mathrm{yr}$ and $9.16 \mathrm{~mm} / \mathrm{yr}$ ). Tidal notches occur in all limestone formations. They were surveyed in 8 sites (Fig. 3). At Dwejra (western Gozitan coast) and Gebel Tal-Halfa (Southeastern Gozitan coast) tidal notches show a vermetid trottoir at the mean sea level (Fig. 5A). Schembri et al. (2005) suggested that differences in the biotic assemblages between Globigerina and Coralline Limestone shores in the Maltese Islands do not appear to be related to differences in exposure or slope. We found the widest vermetid rims $1 \mathrm{~km}$ East from Mgarr Ix-Xini (Fig. 8A), in the southern protected sector or in the small sheltered bay close to Gebel Tal-Halfa and at Dwejra, in an exposed sector, but quite sheltered site in western Gozo. In general, tidal notches, on the contrary of roof notches, seem to develop preferably in sheltered, or quite sheltered, sites.

Comparing the lithology (Fig. 1) and the sectors of the coast with roof notches (Fig. 3), it is widespread at the present-day mean sea level down to $\max -7 /-10 \mathrm{~m}$ m.s.l., in correspondence of most of the Lower Coralline Limestone plunging cliffs and, at a lesser extent along Globigerina Limestone and Upper Coralline Limestone cliffs. This is due to the topographical setting of the cliffs, which are vertical in correspondence of the Lower Coralline Limestone. The roof notch is particularly well-carved along the western and northern coast of Gozo and it occurs almost always together with a submerged marine terrace, $2 \mathrm{~m}-10 \mathrm{~m}$ wide and gently inclined seaward (Fig. 9). The roof notch seems to represents a late Holocene remnant. The system "roof notch-submerged terrace" seems to be related to the late Holocene sea level rise. Lambeck et al. (2011) suggested that the sea level was at about $-10 \mathrm{~m}$ to $-7 \mathrm{~m}$ between 7 kyr BP and 6 Kyrs BP and Furlani et al. (2013) suggested that Maltese islands were tectonically stable during the Holocene. As a consequence, an increasing in the total erosion occurred during the late Holocene slowdown of the sea level rise (Lambeck et al., 2011). This process determined an indentation along most of the plunging cliffs from the submerged terrace to the present-day mean sea level (Fig. 9). On the contrary, no double notches sensu Antonioli et al., (2006) in the Mediterranean, or Focke (1978) in the tropics were found. The lacking of MIS5.5 data, such as notches above mean sea level, in the Maltese island (Paskoff \& Sanlaville, 1978; Furlani et al., 2013) is also confirmed in this survey, because notches develop only around present-day mean sea level.

20 submarine springs were observed and mapped for the first time in the study area. They are located mainly along the western and southern coast in Gozo, while in Comino they occur along the eastern coast (Fig. 3). Higgins (1980) and Furlani et al. (2014a, 2014b) suggested a good correlation between the occurrence of submarine springs and marine notches respectively in the Aegean Sea and NE Adriatic Sea. Available data show no close relations between the submarine freshwater and tidal or roof notches can be

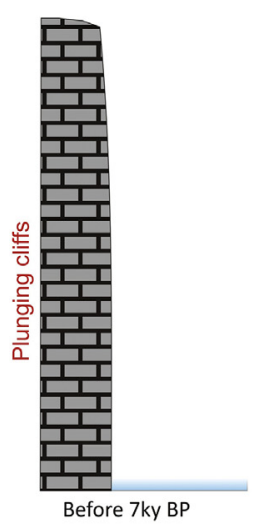

STAGE 1

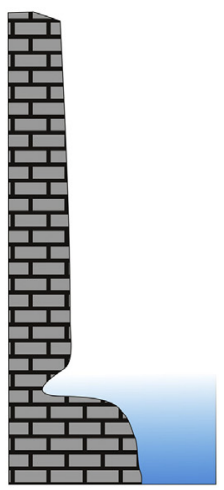

About 6-7ky BP

STAGE 2

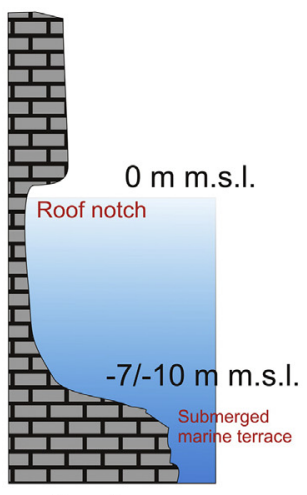

Nowadays

STAGE 3

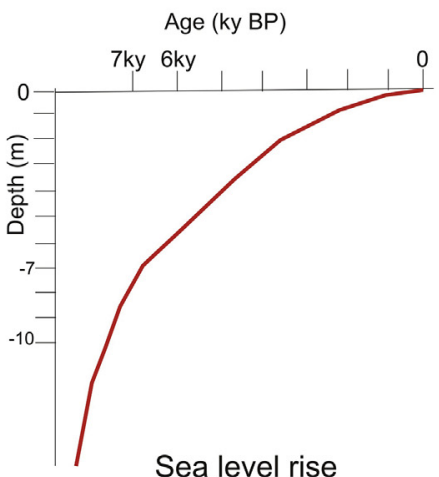

Sea level rise

Fig. 9. Sketch of the formation of the roof notch and the submarine platform in the study area. 
observe, as in the aforementioned areas, because notches occur also in absence of submarine springs. The "open water" conditions of the Sicily Channel with respect to the sheltered Adriatic or Aegean Sea can determine this difference, because submarine freshwaters can be completely diluted when they outflow into the sea. Sea temperature, in fact, does not lower in correspondence of submarine springs, except inside the sea caves, where the temperature is significantly lower than outside (Fig. 6, Table 2). As a consequence, the efficiency of corrosion processes related to the mixing waters (Higgins, 1980; Dreybrodt 1981) in the study area can be significantly lowered with respect to the aforementioned basins. It means that tidal and roof notches development in the Sicily Channel can be ascribed almost completely to bioerosion processes.

\section{Conclusions}

Field data collected during the first complete detailed survey of the rocky coastline of Gozo and Comino (56 km) were presented in this paper. We carried out the first complete and detailed field survey of the island of Gozo and Comino, collecting hydrogeological and geomorphological data for studying late Holocene sea level changes and rocky coast evolution in the central Mediterranean area.

The survey highlighted the presence of a roof notch well-carved at the present-day mean sea level along the Gozitan plunging cliffs and small sectors of Comino. It is often combined with a presently submerged marine terrace, at $-7 \mathrm{~m}$ to $-10 \mathrm{~m} \mathrm{~m}$.s.l. The "roof notch marine terrace" system represents the remnant of the late Holocene slowdown in sea level rise, and the consequent increasing in the total amount of erosion of the submerged part of the cliffs. On the contrary, tidal notches were found only in 8 sites and only at 2 sites they are coupled with a vermetid trottoir at the mean sea level. In Gozo and Comino, roof notches and tidal notches seem to be not related to the nearby submarine springs as in the Aegean Sea and Adriatic Sea. The lacking of MIS5e notches was confirmed with the present research, not only in Malta, but in the entire Maltese islands, so the tectonic stability of the Maltese coast is therefore also confirmed.

Only a geomorphological survey with a continuous snorkeling allowed us to obtain field data to study the late Holocene rocky coast evolution in one of the few sites with carbonate rocks in the Sicily Channel.

\section{Acknowledgements}

The authors wish to thank all the people who have supported the Geoswim2.0 Project, in particular Rados Furlani and Giulio Guglielmi for their technical assistance, Federica Muro, Rylan Patissier, Manuela Rizzo, Giorgia Rosset and Luca Terribili for their precious field assistance. Special thanks to Carlo Fantoni and Martina Zaccariotto for the psychological assistance during the survey. Kindly thanks to SUUNTO through Subaqua Supplies (Malta) for having made available waterproof watches equipped with GPS. This project was sponsored by Medflood2.0 Project (INQUA Project, 1203P, Sponsoring Commission CMP, Project leader 2013, Stefano Furlani). This project was supported and funded by the University of Malta (EuroMediterranean Centre on Insular Dynamics, Institute of Earth Systems), Department of Mathematics and Geosciences, University of Trieste (Prof. Franco Cucchi fundings) and ENEA-UTMEA. We thank also Dr. Sara Biolchi for her precious assistance for the figures.

\section{References}

Antonioli, F., Ferranti, L., Kershaw, S., 2006. A glacial isostatic adjustment for the double MIS 5.5 and Holocene marine notches in the coastline of Italy. Quaternary International 145-146 (1), 9-29.
Antonioli, F., Anzidei, M., Lambeck, K., et al., 2007. Sea level change during Holocene from Sardinia and northeastern Adriatic (Central Mediterranean sea) from archaeological and geomorphological data. Quaternary Science Reviews 26, 2463-2496.

Antonioli, F., Lo Presti, V., Anzidei, M., Deiana, G., De Sabata, E., Ferranti, L., Furlani, S., Mastronuzzi, G., Orru', P., Pagliarulo, R., Rovere, A., Sannino, G., Sanso', P., Scicchitano, G., Spampinato, C.R., Vacchi, M., Vecchio, A., 2015. Tidal notches in the Mediterranean Sea. Quaternary Science Review 119, 1-19.

Anzidei, M., Lambeck, K., Antonioli, F., Furlani, S., Mastronuzzi, G., Serpelloni, E., Vannucci, G., 2014. Coastal structure, sea-level changes and vertical motion of the land in the Mediterranean. In: Martini, I.P., Wanless, H.R. (Eds.), Sedimentary Coastal Zones from High to Low Latitudes: Similarities and Differences, Geological Society. Special Publications 388, London, pp. 453-479.

Azzopardi, L., Schembri, P.J., 1997. Vermetid crusts from the Maltese islands (central Mediterranean). Marine Life 7 (1-2), 7-16.

Benac, Č., Juračić, M., Bakran-Petricioli, T., 2004. Submerged tidal notches in the Rijeka Bay NE Adriatic Sea: indicators of relative sea-level change and of recent tectonic movements. Marine Geology 212 (1-4), 21-33.

Benac, Č., Juračić, M., Blašković, I., 2008. Tidal notches in Vinodol channel and Bakar bay, NE Adriatic Sea: indicators of recent tectonics. Marine Geology 248 (3-4), $151-160$.

Biolchi, S., Furlani, S., Devoto, S., Gauci, R., Castaldini, D., Soldati, M., 2016. Geomorphological recognition, classification and spatial distribution of coastal landforms of Malta. Journal of Maps 12 (1), 87-99.

British Admiralty and U.S. charts, 1996. Islands of Malta and Ghawdex (Gozo), 1: 75,000 scale. Defence Mapping Agency.

Cachia, C., Mifsud, C., Sammut, P.M., 1993. An Annotated Check-list of the Marine Mollusca of the Maltese Islands. Erste Vorarlberger Malakologische Gesellschaft, Rankweil, Austria, p. 80.

Carobene, L., 1972. Osservazioni sui solchi di battente attuali ed antichi nel Golfo di Orosei in Sardegna. Memorie della Società Geologica Italiana 19, 641-649.

Carobene, L., Pasini, G., 1982. Contributo alla conoscenza del Pleistocene superiore e dell'Olocene nel Golfo di Orosei (Sardegna Orientale). Bollettino Società Adriatica di Scienze 64, 5-36.

Chetcuti, D., Buhagiar, A., Schembri, P.J., Ventura, F., 1992. The Climate of the Maltese Islands: a Review. Malta University Press, Msida.

Devoto, S., Biolchi, S., Bruschi, V.M., Furlani, S., Mantovani, M., Piacentini, D., Pasuto, A., Soldati, M., 2012. Geomorphological map of the NW coast of the Island of Malta (Mediterranean sea). Journal of Maps 8 (1), 33-40.

Drago, A., 2009. Sea level variability and the 'Milghuba' seiche oscillations in the northern coast of Malta, Central Mediterranean. Physics and Chemistry of the Earth 34, 948-970.

Dreybrodt, W., 1981. Mixing corrosion in CaC03-C02-H20 systems and its role in karstification of limestone areas. Chemical Geology 32, 221-236.

Ellenberg, L., 1983. Die Kunsten von Gozo. Essener Geographisches Arbeit 6, 129-160.

Evelpidou, N., Kampolis, I., Pirazzoli, P.A., Vassilopoulos, A., 2012. Global sea-level rise and disappearance of tidal notches. Global and Planetary Changes 92-93, 248-256.

Evelpidou, N., Melini, D., Pirazzoli, P.A., Vassilopoulos, A., 2014. Evidence of repeated late Holocene rapid subsidence in the SE Cyclades (Greece) deduced from submerged notches. International Journal of Earth Sciences 103 (1), 381-395.

Faivre, S., Fouache, E., Ghilardi, M., Antonioli, F., Furlani, S., Kovacic, V., 2011. Relative sea level change in Istria (Croatia) during the last $5 \mathrm{ka}$. Quaternary International 232, 132-143.

Focke, J.W., 1978. Limestone cliff morphology on Curacao (Netherlands Antilles) with special attention to the origin of notches and vermetid/coralline algal surf benches ("corniches", "trottoirs"). Zeitschrifts fur Geomorphologie 22, 329-349.

Furlani, S., 2012. The Geoswim project: snorkel-surveying along $250 \mathrm{~km}$ of the southern and western Istrian coast. Alpine and Mediterranean Quaternary 25 (2), 7-9.

Furlani, S., Cucchi, F., 2013. Downwearing rates of vertical limestone surfaces in the intertidal zone (Gulf of Trieste, Italy). Marine Geology 343, 92-98.

Furlani, S., Cucchi, F., Forti, F., Rossi, A., 2009. Comparison between coastal and inland Karst limestone lowering rates in the northeastern Adriatic Region (Italy and Croatia). Geomorphology 104, 73-81.

Furlani, S., Cucchi, F., Biolchi, S., Odorico, R., 2010. Notches in the Adriatic Sea: genesis and development. Quaternary International 232, 158-168.

Furlani, S., Cucchi, F., Biolchi, S., Odorico, R., 2011. Notches in the Adriatic sea: genesis and development. Quaternary International 232, 158-168.

Furlani, S., Antonioli, F., Biolchi, S., Gambin, T., Gauci, R., Lo Presti, V., Anzidei, M. Devoto, S., Palombo, M., Sulli, A., 2013. Relative sea level change in Malta. Quaternary International 288, 146-157.

Furlani, S., Ninfo, A., Zavagno, E., Paganini, P., Zini, L., Biolchi, S., Antonioli, F., Coren, F., Cucchi, F., 2014a. Submerged notches in Istria and the Gulf of Trieste: results from the Geoswim project. Quaternary International 332, 37-47.

Furlani, S., Pappalardo, M., Gomez-Pujol, L., Chelli, A., 2014b. Mediterranean and Black Sea. In: Kennedy, D.M., Stephenson, W.J., Naylor, L. (Eds.), Rock Coast Geomorphology: a Global Synthesis, pp. 89-123. Geological Society, London, Memoirs 40.

Galdies, C., 2011. The Climate of Malta: Statistics, Trends and Analysis 1951-2010, 8. National Statistics Office, Valletta, p. 45.

Grove, A.T., Rackham, O., 2001. The Nature of Mediterranean Europe. An Ecological History. Yale University press, London.

Higgins, C.G., 1980. Nips, notches, and the solution of coastal limestone: an overview of the problem with examples from Greece. Estuarine and Coastal Science $10,15-30$. 
Kaye, C.A., 1957. The effect of solvent motion on limestone solution. Journal of Geology 65, 35-46.

Kazmér, M., Taboroši, D., 2012. Rapid profiling of marine notches using a handheld laser distance meter. Journal of Coastal Research 28 (4), 964-969.

Lambeck, K., Antonioli, F., Anzidei, M., Ferranti, L., Leoni, G., Scicchitano, G., Silenzi, S., 2011. Sea level change along the Italian coast during the Holocene and projections for the future. Quaternary International 232 (1-2), 250-257.

Malta Maritime Authority, 2003. Malta Significant Wave Height Study. Main Report, p. 43.

Mantovani, M., Devoto, S., Forte, E., Mocnik, A., Pasuto, A., Piacentini, D., Soldati, M., 2013. A multidisciplinary approach for rock spreading and block sliding investigation in the north-western coast of Malta. Landslides 10, 611-622.

Micallef, A., Williams, A.T., 2006. Shore platform denudation measurements along the Maltese coastline. Journal of Coastal Research Special Issue 56, 737-741.

Micallef, A., Foglini, F., Le Bas, T., Angeletti, L., Maselli, V., Pasuto, A., Taviani, M. 2013. The submerged paleolandscape of the Maltese Islands: Morphology, evolution and relation to quaternary environmental change. Marine Geology 335, 129-147.

Moses, C., 2012. Tropical rock coasts: cliff, notch and platform erosion. Progress in Physical Geography 37 (2), 206-226.

Moses, C., Robinson, D., Kazmer, M., Williams, R.B.G., 2014. Toward an improved understanding of erosion rates and tidal notch development on limestone coast in the tropics: 10years of micro-erosion meter measurements, Phang Nga Bay, Thailand. Earth Surface Processes and Landforms 40 (6), 771-782.

Paskoff, R., Sanlaville, P., 1978. Observations geomorphologiques sur les cotes de l'archipel Maltais. Zeitschrift fur Geomorphologie 22, 310-328.

Pedley, H.M., House, M.R., Waugh, B., 1978. The geology of the Pelagian blocks: the Maltese islands. In: Nairn, A.E.M., Kanes, W.H., Stehli, F.G. (Eds.), The Ocean
Basins and Margins, vol. 4B. The Western Mediterranean. Plenum Press, London, pp. 417-433.

Pirazzoli, P.A., 1986. Marine notches. In: van de Plassche, O. (Ed.), Sea-level Research: a Manual for the Collection and Evaluation of Data. Geo Books, Norwich, pp. 361-400.

Pirazzoli, P.A. Laborel, J., Stiros, S.C., 1996. Coastal indicators of rapid uplift and subsidence: examples from crete and other eastern Mediterranean sites. Zeitschrift fur Geomorphologie N.F., Supplement Band 102, 21-35.

Pollacco, J.A., 2000. A Study of the Environmental Hydrogeology of the Maltese Mean Sea Level Aquifer. Unpublished report.

Said, G., Schembri, J.A., 2010. Malta. In: Encyclopedia of the World's Coastal Landforms Bird ECF. Springer, Dordrecht, pp. 751-759.

Schembri, P.J., 1993. Physical geography and ecology of the Maltese Islands: a brief overview. In: Busuttil, S., Lerin, F., Mizzi, L. (Eds.), Malta: Food, Agriculture Fisheries and the Environment, Options Mediterraneennesw, Serie B, Etudes et Recherches, 7, pp. 27-39. Montpellier: CHEAM, 1993.

Schembri, J.A., 2003. Coastal Land Use in the Maltese Islands: a Description and Appraisal. PhD Thesis. University of Durham, p. 393. Unplublished.

Schembri, P.J., Deidun, A., Mallia, A., Mercieca, L., 2005. Rocky shore biotic assemblages of the Maltese Islands (Central Mediterranean): a conservation perspective. Journal of Coastal Research 21 (1), 157-166.

Soldati, M., Tonelli, C., Galve, J.P., 2013. Geomorphological evolution of palaeosinkhole features in the Maltese archipelago (Mediterranean Sea). Geografia Fisica e Dinamica Quaternaria 36, 189-198.

Trenhaile, A.S., 2015. Coastal notches: their morphology, formation, and function. Earth-Science Review 150, 285-304. 